\title{
РЕАЛЬНИЙ І ПОТЕНЦИЙНИЙ КОНФЛІКТ ІНТЕРЕСІВ: ВИНИКНЕННЯ ТА ШЛЯХИ ВРЕГУЛЮВАННЯ
}

\begin{abstract}
У иій статті досліджено та проаналізовано явище конфлікту інтересів на державній службі та запропоновано можливі варіанти превентивних заходів та розробки механізмів щчодо недопущення конфлікту інтересів. У процесі вдосконалення законодавства відбулося розмежування понять «потениійний конфлікт інтересів» $i$ «реальний конфлікт інтересів» залежно від стадії впливу суперечності, шзо виникла у прийнятті рішень чи вчиненні дій посадовцем. Таке розмежування в рамках загального поняття иілком узгоджується з підходом, щуо існує в міжнародній практиці. Очевидний (реальний) конфлікт інтересів стосується ситуачій, коли існує особистий інтерес, який може обгрунтовано вважсатися таким, щуо впливає на виконання посадовием свойх обов язків, навіть якщо такий негативний вплив фактично відсутній. Проте неврегульованість законодавства, відсутність иілісної стратегії та чіткого алгоритму дій щуодо конфлікту інтересів, недостатність санкиій та непрагнення до діяльності контролюючих органів не дають змоги не тільки розв'язати наявні, але й попередити потенційні конфлікти інтересів. Природа представницької функиї̈ержаного службовия вже передбачає наявність певних конфліктів інтересів. Удослідженні детально розглянуто сутність конфлікту інтересів та сформульовано висновок, щзо майже всі корупиійні злочини відбуваються під дією конфлікту інтересів, тобто через владні повноваження задоволення особистих потреб, незаконного збагачення та отримання неправомірних благ. Для вчинення злочину, пов'язаного з корупиією, конфлікт інтересів і є передумовою. Найдієвішими нині методами недопущення надалі конфлікту інтересів у кримінальному діянні є саме превентивні методи. Попередження виникнення конфлікту інтересів та викладення в методичних рекомендаціях Начіонального агентства з питань запобігання корупиії норм мають характер лише рекомендацій, а не наказів. Надзвичайно важливо вживати заходів попередження конфлікту інтересів, законодавчо чітко забезпечити невідворотність покарання за порушення реального конфлікту інтересів відповідно до чинних норм та розробити чітку стратегію стосовно роботи близьких осіб в одному органі.
\end{abstract}

Ключові слова: реальний конфлікт інтересів, потенційний конфлікт інтересів, державна служба, публічна особа, адміністративне правопорушення, протокол.

\section{Pinchuk Vitaliy. Real and potential conflict of interests, origins and ways of settlement}

This article examines and analyzes the phenomenon of conflict of interest in the civil service and suggests possible options for preventive measures and the development of mechanisms to prevent conflicts of interest. In the process of improving the legislation, there was a distinction between the concepts of "potential conflict of interest" and "real conflict of interest" depending on the stage of influence of the contradiction that arose in decision-making or action by the official. This distinction within the general concept is fully consistent with the approach that exists in international practice. Obvious (real) conflict of interest refers to situations where there is a personal interest that can reasonably be considered to affect the performance of an official's duties, even if there is no such negative influence. However, the lack of regulation of the legislation, the lack of a holistic strategy and a clear algorithm of action on conflicts of interest, the lack of sanctions and the reluctance of regulatory authorities do not only resolve existing but also prevent potential conflicts of interest. The nature of the representative function of a civil servant already implies the existence of certain conflicts of interest. The study examines in detail the essence of conflict of interest, and concludes that almost all corruption crimes occur under the influence of conflict of interest, ie through the power to meet personal needs, illicit enrichment and illicit goods. Conflict of interest is a prerequisite for committing a crime related to corruption. The most effective method today and to prevent further conflicts of interest in criminal activity are preventive methods. The prevention of conflicts of interest and the setting of norms in the methodological recommendations of the National Agency for the Prevention of Corruption are only of a recommendatory nature and not a prescriptive one. It is extremely important to take measures to prevent conflicts of interest and to legally ensure the inevitability of punishment for violations of real conflicts of interest in accordance with existing norms and to develop a clear strategy for the work of loved ones in one body.

Key words: real conflict of interests, potential conflict of interests, civil service, public figure, administrative offense, protocol.

Постановка проблеми. Неврегульованість конфліктів інтересів між державними обов’язками посадових осіб та приватними інтересами іє порушенням норм антикорупційного законодавства, його заборон та обмежень, що далі породжує джерело корупції.

У Законі України «Про запобігання корупції» прописані правові та організаційні засади функціонування системи запобігання корупції в Україні, зміст та алгоритм впровадження превентивних

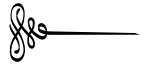


антикорупційних механізмів, створення єдиних правил щодо ліквідації наслідків корупційних правопорушень.

Щоб чітко розуміти сам зміст інституту врегулювання конфлікту інтересів, насамперед треба 3'ясувати сам термін «конфлікт інтересів».

Аналіз останніх досліджень і публікацій. Підгрунтя виникнення та шляхи врегулювання конфлікту інтересів на державній службі досліджували вітчизняні фахівці, а саме: Ю.П. Битяк, М.І. Мельник, К.В. Антонов, С.І. Ніколаюк, Т.Е. Василевська, А.В. Півень, М.І. Пірен та інші.

Мета статті. Головною метою статті $є$ дослідження теоретичного матеріалу та основ інституту державної служби в Україні, їі нормативно-правової площини для визначення шляхів подолання виникнення надалі корупційної складової частини, а саме конфлікту інтересів, які виникають в органах влади та місцевому самоврядуванні під час проходження публічної служби.

Виклад основного матеріалу. Наперед варто зазначити, що конфлікт інтересів в юридичному аспекті $є$ проявом корупції. Базовим документом міжнародного права у сфері запобігання і протидії корупції є Конвенція ООН проти корупції, прийнята резолюцією 58/4 Генеральної Асамблеї від 31.10.2003 р. Вона ратифікована Законом України від 18.10.2006 р. № 251-V «Про ратифікацію Конвенції Організації Об'єднаних Націй проти корупції» і набрала чинності для України 01.01.2010 р. Відповідно до ч. 4 ст. 7 «Публічний сектор» Конвенції,встановлено, що кожна Держава-учасниця прагне, згідно з основоположними принципами свого внутрішнього права, створювати, підтримувати й зміцнювати такі системи, які сприяють прозорості й запобігають виникненню конфлікту інтересів [3].

Публічні керівники, на яких покладені функції управління державними справами, завжди мають дотримуватись жорстких рамок антикорупційного законодавства, попереджувати виникнення будьяких форм конфлікту інтересів.

Ситуації, де можливий конфлікт інтересів, завжди підлягають громадському осуду або обговоренню, пильно контролюються правоохоронними органами, а в разі їх виникнення направляються відповідні повідомлення про порушення шляхом адміністративних протоколів до суду.

Пояснення «конфлікту інтересів» передбачене в Законі України «Про запобігання корупції», що визначає наявність приватного інтересу в тій сфері, де особа виконує свої функціональні обов'язки.

Приватний інтерес у розумінні закону - це будь-який майновий або немайновий інтерес особи, в тому числі зумовлений особистими, сімейними, дружніми або іншими позаслужбовими відносинами 3 фізичними або юридичними особами, в тому числі ті, які виникають у зв'язку з членством або діяльністю в громадських, політичних, релігійних чи інших організаціях [4].

Головним нормативно-правовим актом із цього питання є Закон України № 1700-VII «Про запобігання корупції». Також варто розглянути Закон України «Про службу в органах місцевого самоврядування〉 від 07.06.2001 р. № 2493-III, відповідно до ст. 121 якого посадові особи місцевого самоврядування зобов'язані дотримуватись правил запобігання та врегулювання конфлікту інтересів, передбачених Законом № 1700 [5; 6].

Відповідно до Закону № 1700 розмежовуються 2 види конфлікту інтересів - потенційний та реальний.

Так, згідно із ч. 1 ст. 1 Закону № 1700 реальний конфлікт інтересів - суперечність між приватним інтересом особи та їі службовими чи представницькими повноваженнями, що впливає на об'єктивність або неупередженість прийняття рішень або на вчинення/невчинення дій під час виконання зазначених повноважень.

Потенційний конфлікт інтересів - наявність в особи приватного інтересу у сфері, в якій вона виконує свої службові чи представницькі повноваження, що може вплинути на об'єктивність чи неупередженість прийняття нею рішень або на вчинення/невчинення дій під час виконання зазначених повноважень.

У цьому аспекті доречним буде доповнити визначення реального конфлікту інтересів висновком науково-правової експертизи Ради науково-правових експертиз при Інституті держави і права ім. В.М. Корецького НАН України від 29.04.2016 р. № 126/50-е (ср. 025069200). Отже, реальний конфлікт інтересів варто розуміти так: за його наявності суперечність між наявним приватним інтересом особи та ії службовими чи представницькими повноваженнями безпосередньо впливає (вплинула) на об'єктивність або неупередженість прийнятих рішень або на вчинення/невчинення дій під час виконання вказаних повноважень.

Для визначення факту конфлікту інтересів необхідно встановити:

a) чи наявний конфлікт інтересів;

б) чи суперечить він службовим чи представницьким повноваженням;

в) чи впливає реально така суперечність на об'єктивність або неупередженість прийняття рішень чи вчинення дій. 
Своєю чергою, щоб з'ясувати, чи існує конфлікт інтересів, потрібно визначитись із його об'єктивними компонентами:

- приватний інтерес;

- службове повноваження, представницьке повноваження;

- суперечність між ними, що впливає на об’єктивність або неупередженість рішення;

- діяння службової особи.

1. Приватний інтерес - це будь-який майновий чи немайновий інтерес особи, в тому числі зумовлений особистими, сімейними, дружніми чи іншими позаслужбовими стосунками з фізичними чи юридичними особами, зокрема тими, що виникають у зв'язку із членством або діяльністю в громадських, політичних, релігійних чи інших організаціях. Тобто це означає, що кожен службовець у процесі виконання своїх повноважень має брати до уваги увесь спектр своїх не лише правових (юридичних), а й соціальних (приватних) відносин, які зумовлюють виникнення майнового чи немайнового інтересу. Закон № 1700 не встановлю заборон чи обмежень на наявність приватного інтересу (приватного життя) як такого. Йдеться про дотримання правил етичної поведінки службовця та відповідну оцінку приватних інтересів крізь призму можливого їхнього негативного впливу на об'єктивність прийняття рішень чи діянь службовця під час реалізації своїх службових повноважень.

2. Службове повноваження, представницьке повноваження. Тут мається на увазі, що коло службових повноважень наводиться в посадових інструкціях, трудових договорах та законах України. У цьому контексті потрібно зазначити, що особа має розуміти обсяг своїх повноважень, визначених не лише одним договором чи інструкцією, а можливо, й іншими законами, у тому числі й антикорупційними.

3. Наявність суперечності між інтересом та повноваженнями для реального конфлікту інтересу та можливість виникнення в майбутньому - для потенційного конфлікту інтересу. Наявність суперечності встановлюється в кожному окремому випадку виконання доручення, розгляду листа, здійснення контрольного заходу тощо шляхом порівняння повноважень та наявного в особи приватного інтересу 3 подальшим визначенням можливості (неможливості) такого інтересу вплинути на об'єктивність прийняття рішення, вчинення діяння службовою особою. Важливо розуміти, що конфлікт інтересів існуватиме у всіх випадках, коли в особи $є$ чи настане в майбутньому приватний інтерес, здатний вплинути на об’єктивність рішення, і при цьому така службова особа не має дискреційних повноважень або будьяких інших можливостей, що дозволяють надати комусь перевагу. Відсутність будь-якого складника означає відсутність конфлікту інтересу [3].

Різниця між потенційним та реальним конфліктом інтересів:

- суперечність між приватним інтересом та повноваженнями;

- суперечність впливає на результати роботи та прийняття конкретних рішень.

Алгоритм дій відповідно до методичних рекомендацій та вимог Закону України «Про запобігання корупції»:

- вжиття заходів, результатом котрих буде недопущення виникнення реального, потенційного конфлікту інтересів;

- не пізніше наступного робочого дня з моменту, коли держслужбовець дізнався або мав дізнатися про наявну ситуацію з конфліктом інтересів, повідомляти керівництво підприємства, а в разі перебування особи на посаді, яка не передбачає наявності в нього безпосереднього керівника або колегіального органу, - Національне агентство з питань запобігання корупії (НАЗК) або інший визначений законом орган чи колегіальний орган, у процесі виконання повноважень в якому виник конфлікт інтересів відповідно;

- не здійснювати дій, не приймати рішень в умовах реального конфлікту інтересів;

- вжити заходів щодо врегулювання ситуації, яка склалась [5].

Проаналізувавши положення Закону, варто звернути увагу на обов'язок повідомити керівника або визначений законом орган про конфлікт інтересів, а також не здійснювати дій і не приймати рішень в умовах реального конфлікту інтересів.

Так, за невиконання встановлених законом обов'язків в умовах реального конфлікту інтересів передбачена адміністративна відповідальність.

Положеннями ч. 1 ст. 172-7 Кодексу України про адміністративні правопорушення передбачена відповідальність за неповідомлення особою безпосереднього керівника у випадках, передбачених законом, про наявність реального конфлікту інтересів. Зазначене правопорушення тягне за собою накладення стягнення у вигляді штрафу в розмірі від 1700 до 3400 гривень.

Також положеннями ч. 2 ст. 172-7 зазначеного Кодексу передбачено відповідальність за вчинення дій або прийняття рішень в умовах реального конфлікту інтересів. Таке правопорушення тягне за собою накладення стягнення у вигляді штрафу в розмірі від 3400 до 6800 гривень [7]. 
Найголовнішим наслідком $є$ не штраф як покарання, а внесення особи до Єдиного державного реєстру осіб, які вчинили корупційні або пов'язані з корупцією правопорушення, негайне звільнення з обійманої посади та заборона терміном на 3 роки обіймати відповідні посади державної служби.

Відповідно до положень ст. 11 Закону України «Про запобігання корупції», НАЗК здійснює повноваження щодо забезпечення ведення вищезазначеного реєстру осіб, які вчинили корупційні або пов'язані 3 корупцією правопорушення.

Реєстр є відкритим, безплатним для цілодобового доступу, в ньому зазначаються відомості про фізичну особу, яку притягнуто до відповідальності за вчинення корупційного або пов'язаного з корупцією правопорушення: прізвище, ім'я, по батькові; місце роботи, посада на час вчинення корупційного або пов'язаного з корупцією правопорушення; склад корупційного або пов'язаного з корупцією правопорушення; вид покарання (стягнення).

Аналогічна позиція міститься в Методичних рекомендаціях із питань запобігання та врегулювання конфлікту інтересів у діяльності осіб, уповноважених на виконання функцій держави або місцевого самоврядування, і прирівняних до них осіб, затверджених 14.07.2016 р. Рішенням Національного агентства $з$ питань запобігання корупції № 2 [4].

Висновки і пропозиції. Проаналізувавши практику та дійшовши висновку стосовно встановлення фактів прийняття рішень і розмежування двох видів конфлікту інтересів, у разі реального конфлікту інтересів особа у процесі здійснення та кваліфікації рішення має встановити факти, які будуть впливати на саму кваліфікацію проступку: чітке формулювання факту і наявності приватного інтересу; суперечність представницьких повноважень та приватного інтересу з подальшим прийняттям рішень у корисливих цілях; прийняття рішення в умовах представницьких повноважень; вплив на об'єктивність прийняття рішень. За відсутності хоча б одного з фактів реальний конфлікт інтересів втрачає своє існування. Тому в протоколі про адміністративне правопорушення мають чітко і структурно відображатись вищезазначені факти.

3 висновків судової практики відомі приклади порушень лише з виплати матеріальних заохочень собі і близьким особам та надання земельних ділянок в користування тим самим близьким особам із правом приватизації або розпорядження.

\section{Література:}

1. Про державну службу : Закон України від 24 жовтня 2020 р. № 889-VIII / Верховна Рада Украӥни. URL: https://zakon.rada.gov.ua/laws/show/889-19\#Text.

2. Про ратифікацію Конвенції Організації Об’єднаних Націй проти корупції : Закон України 28 квітня 2020р. № 251-V/ Верховна Рада України. URL: https://zakon.rada.gov.ua/laws/show/251-16\#Text.

3. Конфлікт інтересів: коли він виникає і що з ним робити? URL: https://i.factor.ua/ukr/journals/ms/2017/august/issue-8/ article-29800.html.

4. Конфлікт інтересів в роботі публічних службовців: як уникнути і чому про це важливо пам'ятати. URL: https://protocol.ua/ua/konflikt_interesiv_v_roboti_publichnih_slugbovtsiv_yak_uniknuti_i_chomu_pro_tse_vaglivo_pam_ yatati/.

5. Про запобігання корупції : Закон України від 14 жовтня 2014 р. № 1700-VII / Верховна Рада України. URL: https://zakon.rada.gov.ua/laws/show/1700-18\#Text.

6. Про службу в органах місцевого самоврядування : Закон України від 7 червня 2001 р. № 2493-III / Верховна Рада України. URL: https://zakon.rada.gov.ua/laws/show/2493-14\#Text.

7. Кодекс адміністративного судочинства : Кодекс України від 6 липня 2005 р. № 2747-IV / Верховна Рада України. URL: https://zakon.rada.gov.ua/laws/show/2747-15\#Text. 